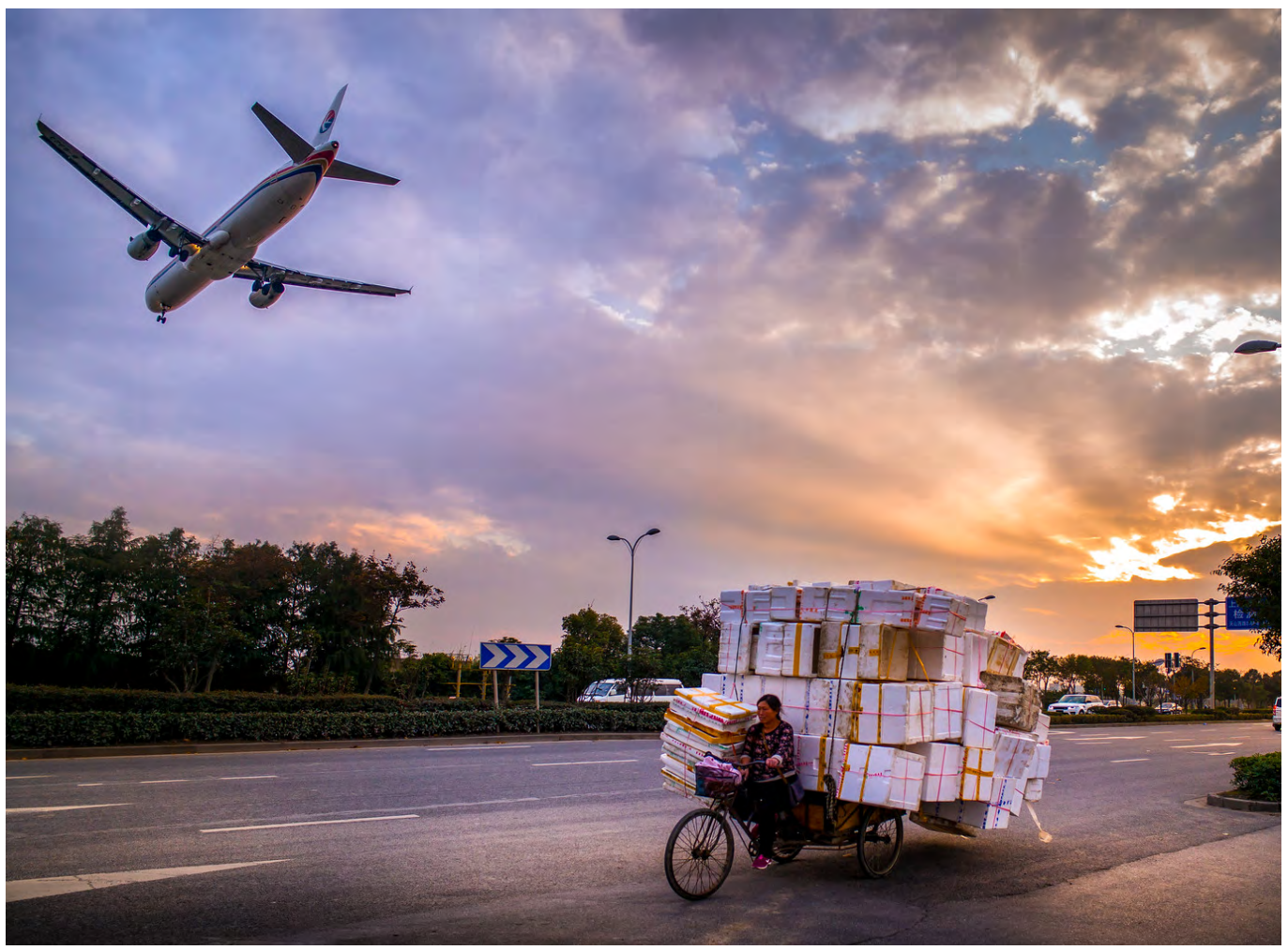

\title{
Migration and the Globalisation of Chinese Capital
}

'Pilots', Shanghai.

PC: photorobsmith.com.

NYÍRI Pál

The globalisation of capital from the People's Republic of China has been accompanied by a growing range of human flows. Since the late 1980s, small traders selling consumer goods, labour migrants working on state projects, and students have expanded to much of the world and been joined by expatriate managers and technicians, tourists and lifestyle migrants. These flows play different roles in the global geography of capital from China, carrying with them distinct modalities of labour relations that involve both Chinese and non-Chinese actors.
A s with the United Kingdom in the nineteenth century and the United States in the twentieth, the rise-or, rather, the return-of the People's Republic of China (PRC) to global economic and political prominence has been accompanied by new migrations within, from, and to China. These have been facilitated by the global economic transformation that followed the end of the Cold War but go back to the death of Mao Zedong in 1976. The Maoist regime of closed borders-which had never been as hermetic as 
its Soviet prototype-began to loosen in the mid1970s, when a trickle of family members of preWorld War II migrants to Hong Kong, Macau, North America, and Europe-overwhelmingly from rural Zhejiang, Guangdong, and Fujian provinces-were allowed to rejoin their relatives as family reunion immigrants. After 1977, official policy permitted family members of overseas Chinese, as well as those overseas Chinese who had previously returned to China, to emigrate. In addition, an increasing number of university students and faculty were permitted to pursue postgraduate studies abroad. Although this was intended to develop science and technology in China, most of these students did not return.

Beginning in 1979, some state companies were given the licence and encouragement to send workers abroad, mostly to work on construction contracts, as a way of generating foreign currency. The scope of contract work has since expanded to services, agriculture, shipping, and manufacturing, while the numbers of those in the construction sector have expanded owing to the increasing role of Chinese companies in road, railway, and dam construction across the world (Zhang 2020). According to official figures from the China International Contractors Association (cited in Nyíri 2018: 706), there were 820,000 Chinese contract workers abroad at the end of 2009. As a shortage of workers developed in China and wages rose, and as criticism of the use of Chinese labour on overseas construction projects intensified in the recipient countries, the outward flows of contract workers declined: in 2017, 522,000 Chinese went abroad, mostly to Asia and Africa (Ministry of Commerce 2018). As infrastructure projects in China slow, these flows may increase again, especially if the Belt and Road Initiative continues despite the global tightening of trade and migration barriers.

As several essays in this issue of the Made in China Journal demonstrate, the encounters of Chinese labour with places outside China can serve as a window into socioeconomic hierarchies and aspirations in China itself, as well as a lens through which to view evolving Chinese understandings of the world. The nature of these encounters has been shifting as Chinese labour contracting expands to a broader range of geographies and projects and the composition of workers becomes more stratified due to subcontracting cascades, differences between state-owned and private companies, and the stratification between skilled workers/technicians and unskilled labour (see, for example, Driessen 2019). Numerically, however-in contrast to the early twentieth century-the significance of contract labour migration for post-Mao China has been limited as, since the 1990s, it has been eclipsed by various outflows of the highly skilled and the well-to-do. Along with students, these include three main groups: traders; growing numbers of highly educated transients, such as the expatriate managers and engineers supporting the worldwide expansion of Chinese companies; and affluent Chinese who choose to live abroad for lifestyle reasons. For this last, growing segment of the urban middle class, moving abroad has shifted from a moneymaking pursuit to a quest for a healthier environment, a more leisurely lifestyle, and happier childhoods for their children.

\section{Traders}

In 1986, China liberalised the issuing of passports, creating the possibility for individuals to go abroad on their own initiative (exit visas were abolished in 1996, and obtaining a passport became a legal entitlement in 2007). The number of Chinese citizens who went abroad jumped from 80,000 in 1986 to nearly 250,000 in 1989 (Nyíri 2018: 707). Chinese traders took advantage of the new provisions, combined with liberalised entry regulations and an unmet demand for consumer goods, to cross the border with the Soviet Union to sell low-price clothing and footwear there and in Eastern Europe. They tied their livelihoods to the ability of Chinese industry 
to deliver products wanted elsewhere, acting as a grassroots vanguard for the subsequent global expansion of Chinese companies, and becoming some of the first to bank on what is now referred to as 'China's rise'.

Most early migrants were former employees of state enterprises who sought a way out of the economic recession and political uncertainty of early 1990s China. Along with millions of others who 'jumped into the sea' (下海, the period term for going into small business), they tested foreign waters. Although no reliable figures are available, at least hundreds of thousands of such entrepreneurial migrants settled abroad, establishing wholesale and retail chains across Eastern Europe, Africa, and, to a lesser extent, elsewhere.

With the subsequent growth of the Chinese economy, the appeal to the highly educated of such low-end entrepreneurship subsided. Instead, rural Fujian, Zhejiang, Henan, Hunan, and Sichuan provinces became new bases of a rapidly expanding entrepreneurial migration to Africa, South America, and mainland Southeast Asia. These migrants numbered in the hundreds of thousands and encountered increasing hostility. In addition to trading consumer goods, entrepreneurial Chinese migrants have in some countries (such as Argentina) taken over much of the food retail industry, while also investing in real estate and hotels. They also increasingly strive to become subcontractors and brokers to large-scale, state-financed infrastructure, extraction, and manufacturing projects carried out by Chinese companies.

The spatial organisation of this migration was centred on 'Chinese markets' or 'Chinese malls', where hundreds, sometimes thousands, of migrant traders served customers from across the region. Like 'Chinatowns' in earlier times, they also served as first points of orientation for new arrivals, as information exchanges, and as recreational environments. In time, these markets evolved into regional wholesale centres with an expanded range of Chinesemade goods, from electronics to household appliances, white goods, and construction material. Dragon Mart, a 1.2-kilometre-long Chinese market in Dubai, has nearly 4,000 shops. These markets are connected by global Chinese-owned networks that provide formal and informal credit and logistics services.

Since the late 2000s, when overseas investments from China increased, some of the malls became bases for 'logistics centres'no longer mere hubs of migrant traders but clusters of larger Chinese companies seeking to gain a foothold in overseas markets and preferring bounded environments owned and managed by Chinese entrepreneurs and staff. These sometimes combine retail, exhibition, and office spaces with residential and recreational ones marketed to relatively highincome buyers in China. Such projects thus link entrepreneurial migration to the migration of expatriate managers and lifestyle migration. At the same time, they employ local workersmostly women, often from marginalised groups such as foreign migrants or ethnic minorities. For such workers, Chinese market stalls or shops have offered ways to find informal employment in environments where their access to other jobs may be limited. Chinese traders often rely on locals as brokers and interpreters, which places them in relationships of trust but also generates conflict (Nyíri 2011; Giese 2013). In some rural locations, working at the Chinese shop is one of the few jobs available; the threat of the closure of village shops in Eastern Europe during the COVID-19 epidemic has left many employees in a desperate situation.

\section{Expatriate Managers}

In addition to blue-collar contract workers, the global expansion of the Chinese economy since the 1990s has resulted in the emergence of a sizeable class of expatriate managers, engineers, and technicians deployed by Chinese companies. Their ranks expanded with the three waves of Chinese corporate globalisation that moved from extractive industries to business-to-business technology and then to 
consumer technology. The first expatriates tended to work on construction projects, in mines, and on oil rigs; later, they were joined by the staff of a few giant information technology (IT) companies. According to its 2010 annual report, the best known of China's globalised companies, Huawei, had offices in more than 140 countries and 21,700 foreign employees, with an overall 'localisation rate' (that is, the share of locally hired employees) of 69 per cent.

After the 2008 Global Financial Crisis (GFC) accelerated the acquisition of overseas businesses by Chinese capital, the range of geographies, industries, and types of companies employing expatriates expanded as smaller businesses ventured abroad. Many expatriate managers were tasked with building and managing local teams. This expanded scope of operations, in turn, needed a wider corporate services infrastructure, such as legal and accounting firms, contractors, and consultancies, both Chinese and non-Chineseowned, which hired a fresh cohort of staff from China to handle the accounts of Chinese firms.

Until the early 2000s, Chinese expatriates tended to be middle-age men from state enterprises who lived in segregated compounds. The expansion of company profiles and locations has resulted in a shift towards young, mostly single men and women, often hired straight out of college either in China or in the West. The middle-class consumption and leisure habits of these employees, who tend to live in urban environments amid non-Chinese, are different from both traders and older stateenterprise managers. Their work interactions with non-Chinese are also of a different nature; while local employees tend to be de facto subordinate to senior Chinese managers and a degree of segregation and mistrust often persists between Chinese and non-Chinese employees, office interaction follows rules that, at least in principle, enforce a more equal relationship with local white-collar colleagues.

Relations with local workers on the shop floor remain a potential point of tension even as the location and sectors of Chinese manufacturing investments shift from poorer to richer countries and from extractive to highertechnology sectors, but to what extent this is so is so far poorly understood. In some cases, Chinese managers bring more demanding labour regimes, but this does not always result in the sort of racialised antagonism that has been observed in some mines in Africa (Lee 2017; Nyíri and Xu 2017). Here, too, differences across locations and sectors and between state and private capital may be significant. In some places, locally born or educated ethnic Chinese play the role of intermediaries between the Chinese management and local workers. As Chinese companies turn into multinationals, develop regional and global networks of manufacturing, logistics, and research and development (R\&D) facilities, and recruit an expanding pool of foreigners, reporting lines and labour relations increase in complexity.

\section{Lifestyle Migrants}

Since the 1990s, a small number of wealthy Chinese entrepreneurs and highly placed officials has sought to gain a foothold abroad to secure their families and their wealth in case of political or economic problems in China (Xiang 2016). The GFC of 2008 and the continued rise of incomes and real estate prices in China made such plans affordable for an increasing segment of the Chinese population.

Between 2009 and 2018, Chinese citizens accounted for half of all those granted EB-5 investor immigrant visas to the United States for employment-generating investments of at least US $\$ 500,000$; for 87 per cent of immigrants under Australia's Significant Investor Program (EB-5 Blog 2019; Department of Home Affairs 2020); and the majority of applicants under Canada's Business Immigration Program, which was ended in 2012 (Canadian Government 2014). So-called golden visa programs in European Union (EU) member states-including Spain, Hungary, and Greecewhich require investments of $€ 300,000$ or more, attracted similar percentages of Chinese 
applicants in the 2010s (Nyíri and Beck 2020). Immigrants from China became the largest foreign buyers of residential real estate in all of these countries. In a 2017 survey of Chinese millionaires (in dollar terms), 47 per cent said they were considering emigration (Hurun Report 2018). The United States was their favoured destination, followed by the United Kingdom, Canada, Australia, and EU member states offering a 'golden visa'.

Increasingly,

investment-immigration schemes attract not only the very wealthy but also middle-class Chinese, who are motivated less by securing their fortunes and more by the desire to live a healthier or more satisfying life (Liu-Farrer 2016; Nyíri and Beck 2020). Many young couples, driven by a desire to raise their children in a more relaxed environment, finance the costs of migration by selling an apartment in China.

\section{Chinese Capital and Labour Relations in the WeChat Diaspora}

Each migration flow considered above is connected to the globalisation of capital from the PRC, yet they have distinct sociodemographic profiles and give rise to different sets of labour practices. The export of contract labour-originally a state-led effort to earn foreign currency but now tied to the global expansion of Chinese corporations-results in forms of precarity that highlight blocked pathways of social mobility in China's domestic labour market but often go unrecognised as both employers and observers are more concerned with managing Chinese-local labour conflicts. Trade migration gives rise to small-scale, negotiated, highly local labour arrangements that have stayed below the radar of regulators and statisticians but in which some non-Chinese gain access to the networks, habitus, and tools of transnational Chinese commerce while Chinese traders acquire local

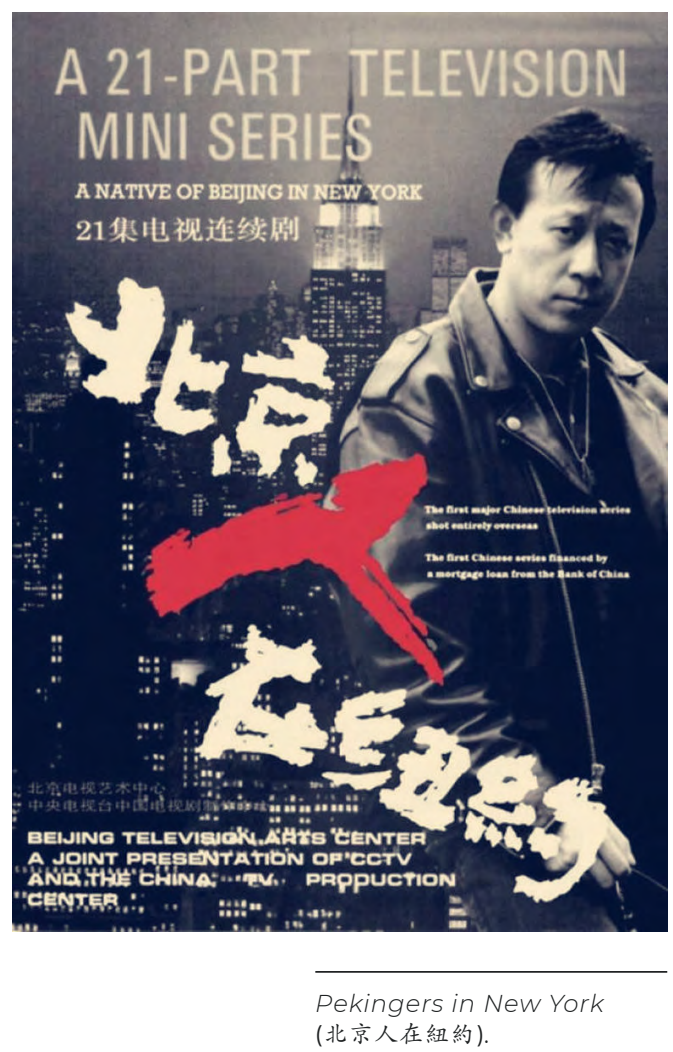

social skills and networks. In contrast, mostly young, educated, and highly mobile expatriate Chinese managers are the vanguard of the PRC's global capitalism. They both export and absorb management practices as they move between frontiers of Chinese capital, connecting places according to a logic that cuts across the old boundaries of 'developed' and 'developing', North and South.

Finally, lifestyle migrants, as they channel PRC capital into the global consumption of real estate, travel, and leisure, help the globalisation of its financial and digital infrastructure. Popular Chinese literature and television of the 1990s were fascinated with the travails of the 'overseas gold-diggers' (海外淘金者). The heroes of these novels and TV dramas-most famously, Glen Cao's Pekingers in New York (北京人在紐約)-were young men who worked their way up from washing dishes in Chinese 


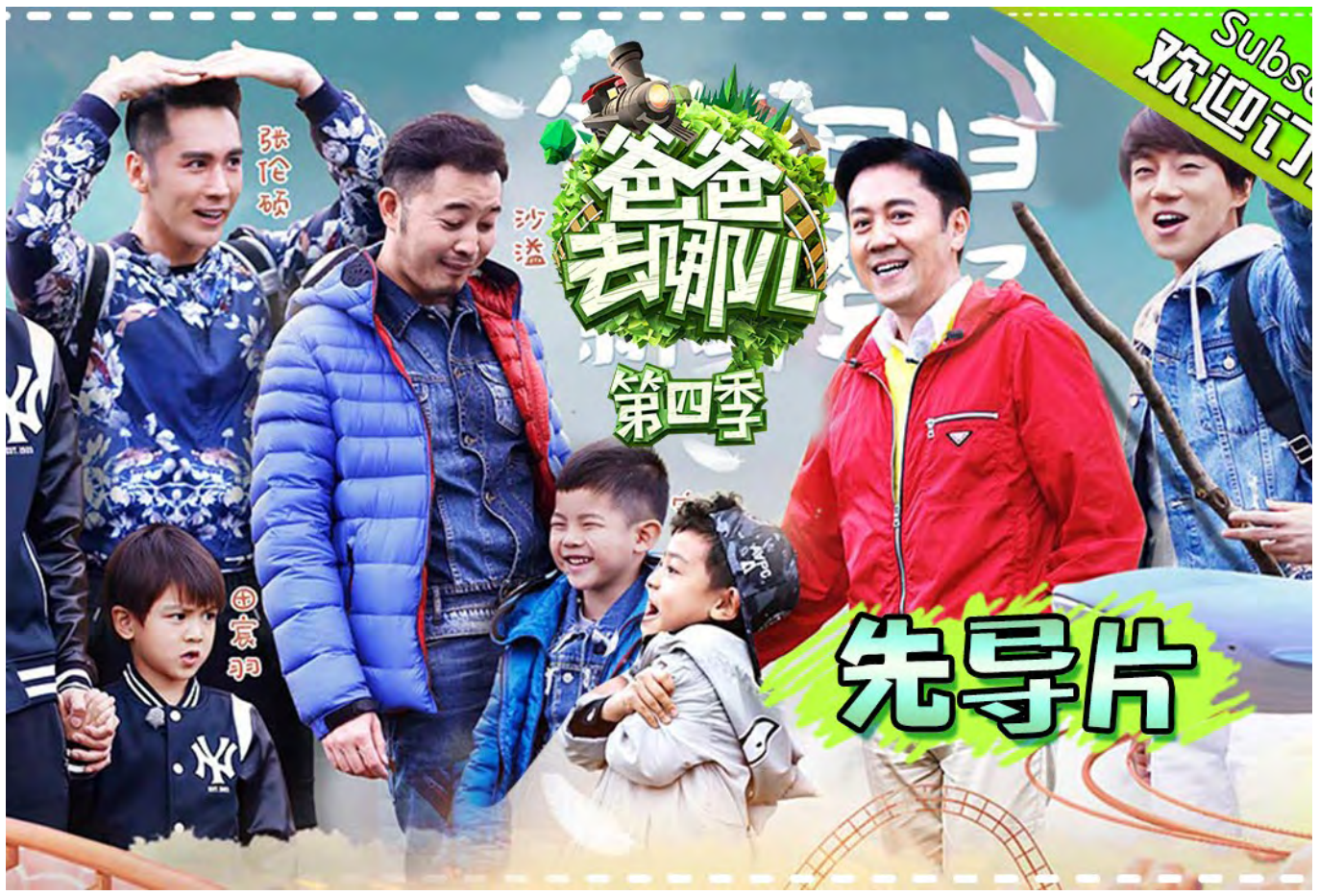

Where Are We Going,

Daddy? (爸爸去哪儿).

restaurants to positions of power and money that commanded respect from the natives (Barmé 1995). Today's popular celebrity shows like Where Are We Going, Daddy? (爸爸去哪儿) feature wealthy Chinese partaking of the culinary and cultural pleasures of the same lands in which their predecessors toiled with such vengeance-and spur more middle-class Chinese to follow (Keane and Zhang 2017).

The transformation of gold-diggers into people of leisure signals this shift in the modality of engagement with the world, from production to consumption-or reproduction, if we see them as paragons of the new nuclear family ideal. Yet such shows, with the travel and migration they help fuel, are themselves fed back into a digital ethnic gig economy that straddles the 'WeChat diaspora' of lifestyle migrants as well as workers, traders, managers, and students (another global human flow from China). This is an immense platform economy that ties together real estate agents, hotel and restaurant employees, travel guides, drivers, accountants, lawyers, media workers, advertisers, and myriad other service providers and proxy buyers (代购) through a system of information and payments channelled through China. Labour relations here are ephemeral and hard to pin down, but they have begun to transform the livelihoods of many in Southeast Asia, Europe, and elsewhere, shaping regional subeconomies that involve particularly, but not only, ethnic Chinese (Nyíri and Tan 2016). . 
This text is taken from Made in China Journal: Volume 5, Issue 3, 2020, edited by Ivan Franceschini and Nicholas Loubere, published 2021 by ANU Press, The Australian National University, Canberra, Australia.

doi.org/10.22459/MIC.05.03.2020.04 